Génét. Sél. Evol., 1985, 17 (1), 89-114

\title{
Evolutionary relationships in the Sativa group of Oryza based on isozyme data
}

\author{
Gérard SECOND * \\ O.R.S.T.O.M. (Institut Français de Recherche Scientifique \\ pour le Développement en Coopération) \\ * Present address : Unité de Biologie des Populations et des Peuplements \\ C.N.R.S., Centre «Louis Emberger», B.P. 5051 \\ F 34033 Montpellier Cedex
}

\begin{abstract}
Summary
The wild and weedy species of the Sativa group of Oryza were studied for their isozyme polymorphism at 24 loci for 181 plants, each taken in a different population, the total representing the entire area of pan-tropical distribution. One to 10 electromorphs were distinguished per locus with an average of 4.1. A multivariate analysis of the data on an individual strain basis showed several important discrepancies with taxonomy based on morphological characters. In particular, the Australian form was largely divergent from the Asian and American forms of O. rufipogon, which were closely related to each other and to $O$. breviligulata. A Chinese form of $O$. rufipogon could be distinguished from a South Asian form although many intermediates existed. The South Asian form of $O$. rufipogon was the most variable of all although it was not possible to distinguish the annual from the perennial life forms at the isozyme level. The electromorph frequencies and the distribution of genetic distances in 2 by 2 strain comparisons were analysed within and between the geographic groups or species. Large values of Nei's genetic distances (up to 1.26) and large proportions of loci with no allele in common (up to 9 out of 24) were found between groups. The closest relationships of the 3 basic isozyme patterns of, indica, japonica and glaberrima cultivated rice were found with South Asian $O$. rufipogon, Chinese $O$. rufipogon and $O$. breviligulata, respectively. It was concluded that the Sativa group was composed of 2 species endemic to Africa $-O$. longistaminata and $O$. breviligulata - and a complex species $O$. rufipogon with South Asian, Chinese, New Guinean, Australian and American geographic forms. How such differentiation has occurred was discussed in relation to : 1) the major tectonic and climatic events in the Old World over the past 15 million years; 2) the independent domestication of rice in South Asia, China and Africa ; 3) the role played by man in carrying seeds across geographic barriers and in disturbing primitive habitats.
\end{abstract}

Key words : Poaceae (= Gramineae), Oryza, isozyme, evolution, domestication.

\section{Résumé}

Les relations évolutives entre lignées du groupe Sativa (génôme AA) d'Oryza $L$. étudiées à 24 locus d'isozymes

Les espèces sauvages et adventices du groupe Sativa du genre Oryza sont étudiées pour leur polymorphisme isozymique à 24 locus sur 181 plantes, chacune prélevée dans une 
population différente et représentant toute l'aire de la distribution pantropicale. De 1 à 10 électromorphes sont distingués à chaque locus avec une moyenne de 4,1 . Une analyse multivariée des résultats lignée par lignée montre plusieurs anomalies importantes par rapport à la taxinomie basée sur des caractères morphologiques. En particulier, la forme australienne est largement divergente des formes asiatiques et américaines d'O. rufipogon, étroitement apparentées entre elles et avec $O$. breviligulata. Une forme chinoise d'O. rufipogon peut être distinguée d'une forme sud-asiatique, bien que de nombreux intermédiaires existent. La forme sud-asiatique d'O. rufipogon est la plus variable de tout le groupe sans que l'on puisse y distinguer les types biologiques annuels et pérennes au niveau des isozymes. Les fréquences d'électromorphes et la distribution des distances génétiques entre lignées 2 à 2 sont analysées parmi les groupes géographiques ou espèces retenus. On observe des distances génétiques (NEI) importantes (jusqu'à 1,26) avec une large proportion de loci sans allèles communs atteignant 9 sur 24 entre groupes. Un apparentement maximal des 3 combinaisons isozymiques de base des riz cultivés, indica, japonica et glaberrima est trouvé avec $O$. rufipogon d'Asie du Sud, O. rufipogon de Chine et $O$. breviligulata, respectivement. Il est conclu que le groupe Sativa est composé de 2 espèces endémiques en Afrique - $O$. longistaminata et $O$. breviligulata - et d'une espèce complexe O. rufipogon avec des formes géographiques d'Asie du Sud. de Chine, de NouvelleGuinée, d'Australie et d'Amérique. On discute comment une telle différenciation est apparue et discutée en liaison avec : 1) les principaux événements tectoniques et climatiques dans l'Ancien Monde depuis 15 millions d'années; 2) la domestication indépendante des riz en Asie du Sud, Chine et Afrique ; 3) le rôle de l'homme dans le transport des graines à travers les barrières géographiques et dans la perturbation des habitats primitifs.

Mots clés : Graminées, Oryza, isozyme, évolution, domestication.

\section{Introduction}

The heterogeneous and world wide tribe Oryzeae is considered on comparative chromosomal and anatomical grounds to be primitive within the grass family (STEBBINS, 1956 ; TATEOKA, 1957). Within the genus Oryza, the genome AA, defined by MORINAGA (1964) on the basis of normal chromosome pairing at meiosis in FI hybrids, corresponds to the Sativa group (MORISHIMA \& OKA, 1960). It comprises the 2 cultivated species $O$. glaberrima and $O$. sativa and the 3 wild or weedy species $O$. rufipogon Griff. (=O. perennis Moench), O. longistaminata A. Chev. et Roer. (sometimes misnamed $O$. barthii A. chev. or O. perennis subsp. barthii) and $O$. breviligulata A. chev. et Roer. (=O. barthii A. Chev.). The importance of the Sativa group lies in its close relationship with cultivated rice. $O$. rufipogon is, by itself, a Complex with various Asian, American and Oceanian forms and perennial, annual and intermediate life forms (MORISHIMA, 1969).

Although numerous crossing barriers are commonly found within the Sativa group (CHU et al., 1969) hybrids between the various species, taxa or life forms, are not generally totally sterile. Gamete sterility, which is the commonest barrier encountered, is generally more pronounced for pollen than for ovules. Introgression of genes from one species to another is possible and occurs spontaneously (ОКA \& ChANG, 1961 ; CHU \& OKA, 1970). Also, some weedy forms seem to have evolved from hybrid swarms between independently domesticated cultivars (SECOND, 1982).

Research on rice isozyme variability began in the mid 1960's in Japan and was reviewed by ENDO \& MORISHIMA (1983). It was limited to esterases, peroxidases and acid phosphatases until SEcond \& Trouslot (1980) extended it to more than 13 different enzyme systems. The genic diversity of cultivated rice and wild and weedy O. breviligulata was studied at 40 isozyme loci by SECOND (1982). 
The morphology and F1 pollen sterility relationships of wild rice was studied extensively in Morishima (1969). However, only O. rufipogon and O. longistaminata were considered and reliable samples from South China were missing. The present report includes the most typical strains studied by Morishima (1969) and, in addition, $O$. breviligulata and samples of $O$. rufipogon recently made available (including a reliable collection from South China). It gives for the first time, as far as the author knows, an overall picture of the isozyme polymorphism of the Sativa group including all its ecogeographic forms as available in collections.

From these data, an attempt has been made to interpret the observed genetic structure, to reconstruct the distribution of the group and its sructure in the paleoenvironment and to determine in which area domestication occurred.

\section{Material and methods}

\section{A. Oryza strains or individuals}

Material studied on 24 isozyme loci included 181 strains (in the case of annual, predominently autogamous forms) or individual plants (in the case of perennial, eventually self incompatible forms) chosen each in a different population among a great number of wild and weedy populations collected across most of the range of the Sativa group distribution. They were obtained from the collections of the National Institute of Genetics (NIG) in Misima (Japan), the Institut Français de Recherche Scientifique pour le Développement en Coopération (ORSTOM) in Ivory Coast, the National Institute of Agricultural Science in Tsukuba (Japan) and the International Rice Research Institute (IRRI) in the Philippines. When available, seeds collected on the original sites were used and the strains were propagated by selfing. In some cases and particularly for the Chinese strains, multiplication of seeds might have been done previously to the accession in unknown conditions. In the case of self compatible O. longistaminata but also for most of the perennial forms of $O$. rufipogon, plants grown from original seeds and vegetatively propagated in green house were used.

In view of the numerous accessions available from Asia and Africa, limited numbers were selected to represent most of the area of distribution and of the ecological origins. For Africa, 20 O. longistaminata plants and 20. O. breviligulata strains collected in populations truly isolated from cultivated fields were selected. For South Asia, only a few of the original populations were really isolated from cultivated rice fields in terms of possible pollen flow ; 361 strains or plants were analysed for some of the loci (see table 2) and showed a complex array of intermixed genotypes. 85 strains or plants were chosen among them, each from a different population, so as to represent as equitably as possible the ecological situations or life forms in the various South Asian geographical origins. They were classified as «weedy " or "wild " according to the location of collection in, or outside, a rice field ; "wild " forms were further classified into " annual », " perennial " or « intermediate annual-perennial » life forms in the sense in use at the moment in the NIG collection (see in particular MorisHIMA et al., 1961). Although based on repeated observations, for most plants or strains, this classification into life forms remained partly ambiguous. All populations or strains available from China (28), New Guinea (5), Australia (10) and America (16) were 


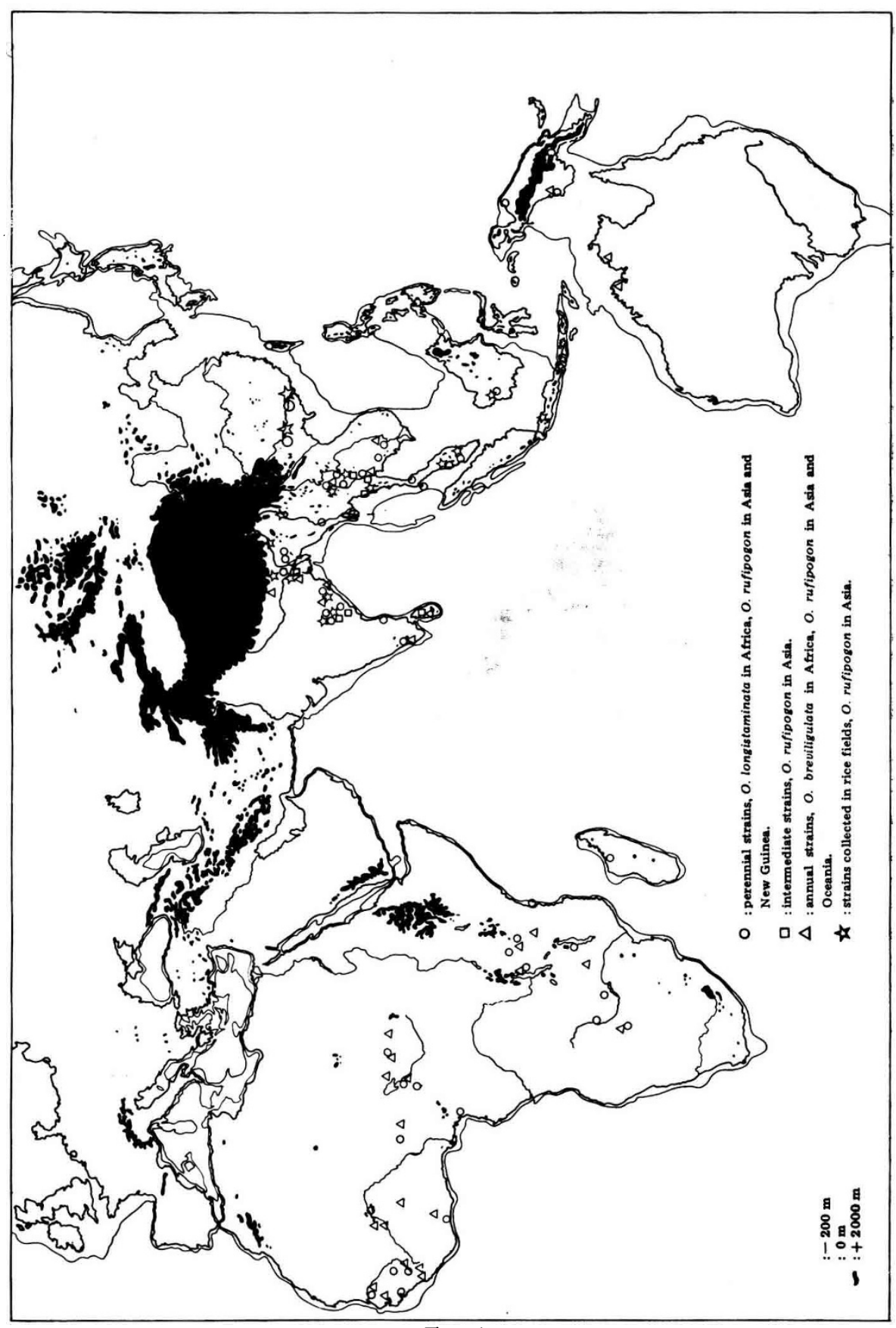

FIG. 1

The geographical origins of the spontaneous strains of the Sativa group studied from the Old World and Australia shown by conventional symbols according to their classification. A dot may correspond to several strains extracted from different populations. The map shows in addition the $-200 \mathrm{~m}$ isobathic line and the areas more than 2000 meters above sea level.

Les origines géographiques des formes spontanées du groupe Sativa étudiées dans l'Ancien Monde et l'Australie. 
selected and represented by one individual. Geographic origins are shown on figure 1 (except for America). The exact location of most Chinese strains was not known in detail but they came from three different origins : 13 were from Kwangsi, 10 from Boluo County in Kwangtung Province and 4 from Taiwan. They belonged to 3 different original collections. The American accessions were from various origins of the Amazon basin and Cuba.

\section{B. Electrophoresis and analysis of isozymes}

Seeds were germinated for 5 to 7 days in distilled water on filter paper. The tip of one coleoptile was cut to perform a preliminary electrophoresis (see table 1). The rest of the same seedling and 2 other seedlings were transplanted the next day on heat-disinfected soil. Usually, the cut seedling survived and the same plant was further analysed or another plant of the same accession number was used. In the case of plants vegetatively propaged, a preliminary electrophoresis was done on the white part of a growing leaf. Another part of a growing leaf and a blade of a young but developed leaf where further sampled and immediately used for electrophoresis, according to the scoring sequence exposed in table 1 . The samples were crushed in distilled water and subjected to horizontal starch gel electrophoresis with only minor modifications (indicated in a forthcoming paper) of the technique described in SEcond \& Trouslot (1980) and SEcond (1982).

\section{TABLE 1}

Scoring sequence of the 24 loci at 3 different plant stages and 3 different buffer systems.

Séquence de lecture des 24 locus à 3 stades différents avec 3 systèmes de tampons.

\begin{tabular}{|c|c|c|c|}
\hline \multirow{2}{*}{ Stage } & \multicolumn{3}{|c|}{ Buffer systems } \\
\hline & Histidine $\mathrm{pH} 8.0$ & Histidine $\mathrm{pH} 6.0$ & Borate $\mathrm{pH} 8.0$ \\
\hline Coleoptile... & $\begin{array}{c}I d h-\mathrm{A} \\
P g m-\mathrm{A} \\
\text { Cat-A } \\
\text { Pgd-A and B } \\
\text { Pgi-A and B }\end{array}$ & & \\
\hline $\begin{array}{l}\text { White part of a gro- } \\
\text { wing leaf } \ldots . . . .\end{array}$ & $\begin{array}{c}(\text { Idh-A }) \\
(P g m-\mathrm{A}) \\
\text { Adh-A }+ \text { To-A } \\
(\text { Cat-A) } \\
(\text { Pgd-A and B) } \\
\text { Gdh-A and B } \\
\text { Pox-B } \\
\text { Est-A }\end{array}$ & $\begin{array}{c}M d h-\mathrm{A}, \mathrm{B} \text { and } \mathrm{C} \\
\text { Lap-E } \\
\text { Est-B and E } \\
\text { Pox-B }\end{array}$ & \\
\hline Developped leaf ... & $\begin{array}{c}(P o x-\mathrm{B}) \\
\text { Pgi-A and B }\end{array}$ & $\begin{array}{c}\text { Got-A and C } \\
\text { Lap-E }+\mathrm{Gp}-\mathrm{A} \\
(\text { Est-B and E) } \\
\text { Pox-B }\end{array}$ & $\begin{array}{l}P x-1 \\
A c p-1\end{array}$ \\
\hline
\end{tabular}

Parentheses indicate a possibility of scoring not always used. Pgi-A and B, Lap-E and Pox-B loci are always scored twice at least. For a given stage and buffer system, loci are listed according to the slicing sequence of the gel plates. 
In this way, the most polymorphic loci were scored twice at least and, if necessary, individuals with similar bands were placed side by side to check for minor differences in migration distances.

At the two highly variable $P g i$ loci, hidden variability was screened by heat treatment as described in SECOND (1982), using a set of slices of the same gel.

\section{Nomenclature of genetic variants}

The electrophoretic or thermostability variants referred to in this paper as electromorphs or electro-thermomorphs are assumed to represent classes of alleles indistinguishable according to the method utilized. The nomenclature for most of them and the criteria used as evidence for the existence of a locus are described elsewhere (SEcond \& Trouslot, 1980 ; Second, 1982).

The loci studied were the following : Alcohol dehydrogenase (Adh-A); Glutamate dehydrogenase, 2 loci ( $G d h-\mathrm{A}, \mathrm{B})$; Malate dehydrogenase, 3 loci $(M d h-\mathrm{A}, \mathrm{B}, \mathrm{C})$; Isocitrate dehydrogenase (Idh-A); Phosphogluconate dehydrogenase, 2 loci (Pgd-A, B) ; Catalase (Cat-A) ; Peroxidase, 2 loci (Pox-B and Px-1, PAI et al., 1973) ; Tetrazolium oxidase (To-A); Aspartate aminotransferase or Glutamate oxaloacetate transferase, 2 loci (Got-A, C) ; Acid phosphatase (Acp-1, PAI et al., 1975) ; Phosphoglucomutase (Pgm-A) ; Esterase, 3 loci (Est-B, E, Ca); Leucine aminopeptidase (Lap-E) ; Glucose-phosphate isomerase, 2 loci $(P g i-A, B)$. In addition the major band of general protein was scored as it appeared in the strain for LAP or ACP with extracts of green leaves. It probably corresponds to the fraction 1 protein (Rubisco) which is known to be encoded by both nuclear and cytoplasmic factors (KUNG, 1976). As variation was observed in only two closely related strains, a single locus was assumed : $G p$.

\section{Results}

\section{A. Electrophoretic data}

A number of zymograms were drawn or pictured in SECOND \& TrousLot (1980). The genetic determinism was largely inferred from their polymorphism observed within and between autogamous and self incompatible species. The simplest genetic interpretation compatible with the observations was adopted. In the case of selfincompatible $O$. longistaminata, agreement was found between observed and expected frequencies of genotypes under the hypothesis of panmixis for all polymorphic loci in this species, with populations of 50 to 200 individuals (SECOND \& TrOUSLOT, 1980 and unpublished data). Further, Mendelian segregations were observed for the loci Mdh-A, Cat-A, Pox-B, Est-E, Lap-E, Pgi-A and B (SECOnd, 1982 and unpublished data). $P x-1$ and $A c p-1$ loci have already been described in more detail (PAI et al., 1973 and 1975). The linkage relationships between these loci are under study by several groups of workers. Clearly, the linkage groups are scattered over many chromosomes (SECOND \& Morishima, 1981 ; A. Ghesouiere, J.L. Lacroix, J.L. Pham, L. SAno, personnal communications). 
Only the To-A locus was found to be completely monomorphic among the 24 loci scored. Two loci had a null electromorph : Est-B and Est-E. A total of 99 electromorphs (4.1/locus) were observed with a maximum of 10 for the Pgi-A locus. Although heterozygotes were frequently observed in cross-pollinated strains, their frequencies were not considered because many lines had been artificially sexually multiplied, generally only once.

It appeared that the interrelationships among strains at the isozyme level did not always reflect their classification on the basis of conventional taxonomy, based on morphological characters, geographic origins or life forms. Prior to analysing the genic diversity within groups of strains or species, each strain was thus considered on an individual basis and a multivariate analysis of its interrelationships with all other strains was studied.

\section{B. Multivariate analysis of the observed genetic differentiation}

Genetic distances (NEI, 1975) were calculated (a) between strains in 2 by 2 comparisons among the 181 strains studied at 24 loci and (b) between each strain and the 3 basic isozyme patterns found in cultivated rice : indica, japonica and glaberrima (Second, 1982, tabl. 6). A multivariate analysis of the generated distances was made by the method of principal coordinate analysis of Gower (in PIELOU, 1969, p.p. 257260).

Four series of analyses were carried out as follows :

1) all strains were included without any a priori classification ;

2) the oceanian forms of $O$. rufipogon and $O$. longistaminata were excluded;

3 ) only the Asian forms of $O$. rufipogon (including those of Chinese origins) were considered, (a) alone and (b) together with the collection of 40 cultivated varieties of $O$. sativa analysed in SECOND (1980);

4) only the $O$. rufipogon strains of South and continental South-East Asian origins were considered with regards to their classification on a life form basis.

The percentage of total variation explained by the first 2 vectors varied between 27 and 31 p. 100 depending on the analysis. It appears to be rather low. However it depends on the criterion used to calculate it. A comparison of the distances on the figures 2 and 3 with the true distances given later in table 3 shows that the overall representation is essentially correct.

When all strains were considered (fig. 2), only $O$. longistaminata and the Oceanian forms of $O$. rufipogon were clearly distinguished. Other strains were in the main cluster. Among the 5 strains of New Guinean origin, 3 were found among the Asian forms of $O$. rufipogon while 2 were close to the Australian strains of $O$. rufipogon according to the classification of the same strains previously made by MoRISHIMA (1969) on the basis of numerical taxonomy and analysis of F1 pollen sterility. The 2 strains classified with the Oceanian form of $O$. rufipogon are nevertheless much different from the Australian strains on morphological grounds (MoRISHIMA, 1969). In figure 2 they are closer to the Asian form of $O$. rufipogon than the Australian strains according to the exact electrophoretic distances given in table 3 . 


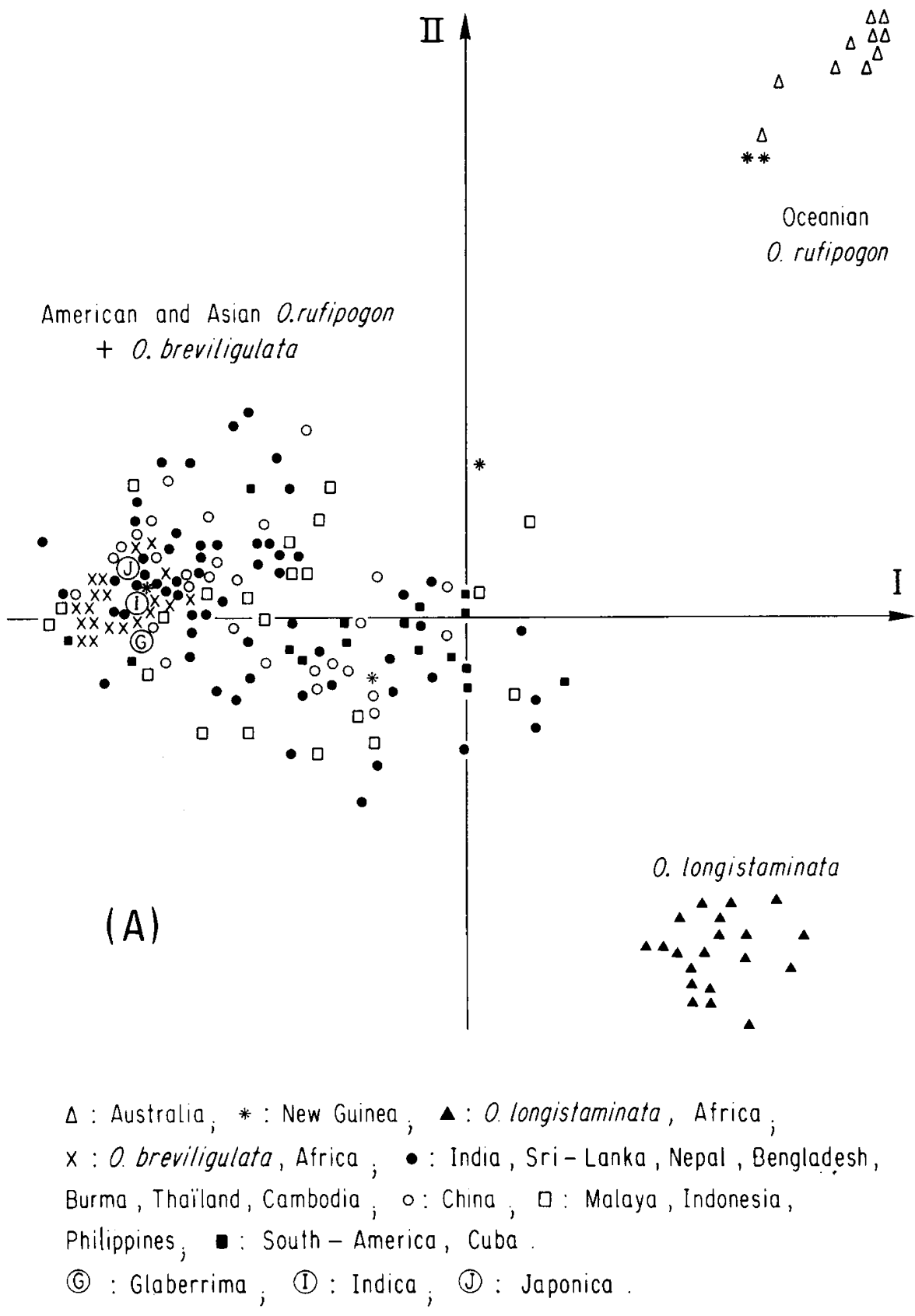

FIG. 2

181 strains of the spontaneous forms of the Sativa group plotted in the first plane of a principal coordinate analysis of the genetic distances in strain comparison at 24 loci. The geographical origins or taxonomic classifications are indicated by a conventional sign. The positionning of cultivated rice is indicated by the 3 basic isozyme patterns of indica, japonica and glaberrima types of cultivars.

181 lignées des formes spontanées du groupe Sativa distribuées dans le premier plan d'une analyse en coordonnées principales de la diversité à 24 locus lue en électrophorèse. 
When the strains of the main cluster only were considered, no group was clearly distinguished but the following origins tended to segregate from others : 1) the strains from China together with the japonica isozyme pattern of cultivated rice on the $1^{\text {st }}$ vector, 2) the strains from America on the $2^{\text {nd }}$ vector and 3) O. breviligulata, together with the glaberrima pattern of cultivated rice, on the $3^{\text {rd }}$ vector.

Figure 3 shows the results on the first plane of an analysis including the Asian strains of $O$. rufipogon and the collection of 40 varieties of $O$. sativa. The variability of wild strains largely exceeded but also included that of cultivars for the most

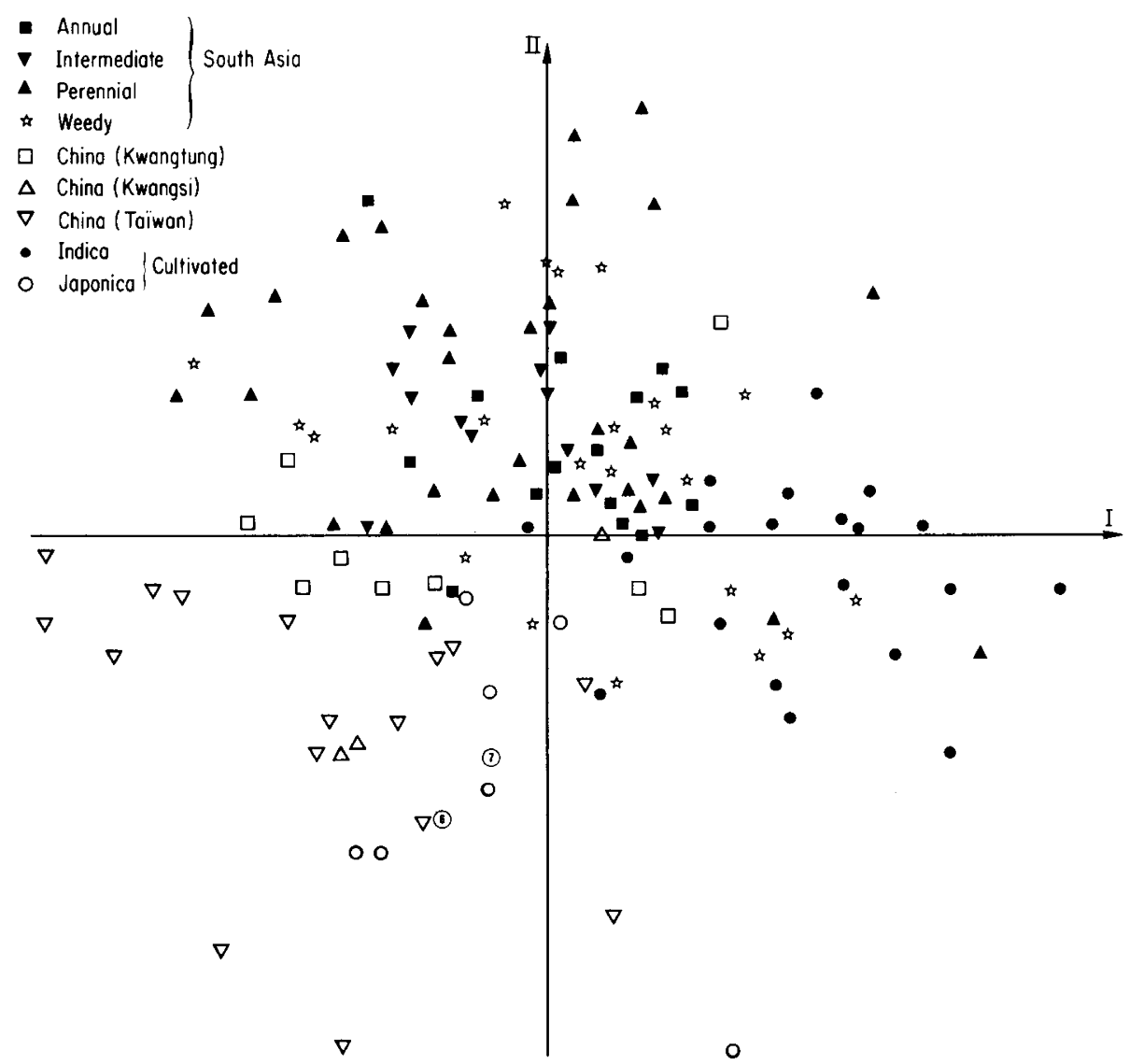

FIG. 3

110 strains of Asian $O$. rufipogon and 40 varieties of 0 . sativa plotted in the first plane of a principal coordinate analysis of the genetic distances in strain comparison at 24 loci. Are indicated by a conventional symbol, the life forms for South Asian O. rufipogon, the 3 different collections for Chinese $O$. rufipogon and the classification in indica and japonica types of $\mathrm{O}$. sativa by the phenol reaction of glumes.

110 lignées des formes spontanées d'O. rufipogon asiatique et une collection de 40 variétés d'O. sativa distribuées dans le premier plan d'une analyse en coordonnées principales de la diversité à 24 locus lue en électrophorèse. 
part. Both axis allowed for the distinction of the positive and negative phenol reaction type of cultivars which is clearly in relation with their differentiation in indica and japonica types (OKA, 1958). Interestingly, the pattern of variation in the wild strains was similar to the main pattern of differentiation in the cultivars. Only wild strains originating in China were found to be closely related to the japonica type of cultivars. There was however a sharp differentiation among the 3 different collections originating in 3 different provinces of China :

- Most strains from Kwangsi province were close to the japonica type although their morphological appearance was typically that of wild rices. They were generally homozygous, sometimes for rare electromorphs at Idh and Pgm loci, unique to them (see later, fig. 4).

- The strains from Kwangtung province were intermediate between the indica and japonica types (Six out of 9 were also heterozygous at such locus as Cat-A related to the indica-japonica differentiation).

- The strains from Taiwan were also close to the japonica type.

On the other hand, only few strains of $O$. rufipogon, most of them weedy, were found together with the indica type of cultivars. Most $O$. rufipogon strains from South Asia were intermediate between the indica and japonica types on the $1^{\text {st }}$ axis but segregated from cultivated rice on the $2^{\text {nd }}$ axis due to their heterozygosity and larger electromorph diversity.

Also apparent from figure 3 , is that no strong association between the genetic diversity and the life form types, as classified here, could be detected. This point was confirmed in round 4 of the multivariate analysis when only the continental SouthAsian strains were considered.

It should be noted that a similar structure was revealed in principal component and factorial analysis of correspondence on the electromorph frequencies $(0,0.5$ or 1 in a given strain). Using the standard genetic distance of NEI, however, less relative weight was given to the rare alleles at the detriment of the overall relationships.

Taking into account, both the above pattern of interrelationships and the phenetic study at the morphological and F1 pollen sterility level of MoRishima (1969), the following subclassification of the Sativa group is suggested on a geographical basis :

1) O. rufipogon, South Asian (SA): This group comprises all South and SouthEast Asian strains, irrespective of life forms. It includes the 3 strains originating in New Guinea with South Asian affinity.

2) O. rufipogon, Chinese (CA) : From China, including Taiwan. It partly overlaps the South Asian group and deserves further studies for its characterization.

3) O. rufipogon, New Guinea $(\mathrm{ON})$ : This group includes the two strains originating in New Guinea but with an Australian affinity.

4) O. rufipogon, Australia (AO).

5) O. rufipogon, America (AM).

6) O. breviligulata in Africa (BV).

7) O. longistaminata in Africa (AL).

8) Cultivated rices with three basic isozyme patterns : japonica (JP), indica (ID) and glaberrima (GL) (SECONI), 1982).

These groups are used for presenting allozyme frequencies data. 
TABLE 2

Electromorph frequencies and mean gene diversity index at 24 loci in the main geographic wild or weedy forms or species of the Sativa group.

Les fréquences d'électromorphes et l'index moyen de diversité génique à 24 locus parmi les principales formes géographiques et espèces sauvages ou adventices du groupe Sativa.

\begin{tabular}{|c|c|c|c|c|c|c|c|c|}
\hline \multirow[b]{2}{*}{ Electromorphs } & \multicolumn{8}{|c|}{ Groups and strains or individuals numbers } \\
\hline & $\begin{array}{l}\text { SA } \\
82\end{array}$ & $\begin{array}{l}\mathrm{SA}^{\prime} \\
173 \\
\text { to } 361\end{array}$ & $\begin{array}{l}\text { CA } \\
28\end{array}$ & $\begin{array}{c}\mathrm{ON} \\
2\end{array}$ & $\begin{array}{l}\text { OA } \\
10\end{array}$ & $\begin{array}{c}\text { AM } \\
16\end{array}$ & $\begin{array}{l}\mathrm{BV} \\
20\end{array}$ & $\begin{array}{l}\text { AL } \\
20\end{array}$ \\
\hline Adh-A & & & & & & & & \\
\hline $\begin{array}{l}1 \\
1 \\
2\end{array} \ldots \ldots \ldots \cdots \cdots$ & .99 & .98 & 1 & 1 & .9 & 1 & 1 & $\begin{array}{l}.98 \\
.02\end{array}$ \\
\hline $3 \ldots \ldots \ldots \ldots$ & .01 & .02 & & & & & & \\
\hline $4 \ldots \ldots \ldots \ldots$ & & & & & .1 & & & \\
\hline Gdh-A & & & & & & & & \\
\hline 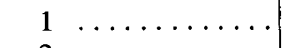 & .99 & & .96 & 1 & 1 & 1 & 1 & .95 \\
\hline $2 \ldots \ldots \ldots \ldots$ & & & & & & & & .05 \\
\hline $3 \ldots \ldots \ldots \ldots$ & .01 & & .04 & & & & & \\
\hline$G d h-\mathrm{B}$ & & & & & & & & \\
\hline $\begin{array}{l}1 \\
2\end{array}$ & 1 & & 1 & 1 & 1 & 1 & 1 & 1 \\
\hline$M d h-\mathrm{A}$ & & & & & & & & \\
\hline $1 \ldots \ldots \ldots \ldots$ & .98 & .94 & 1 & 1 & 1 & 1 & .90 & .95 \\
\hline $2 \ldots \ldots \ldots \ldots$ & .01 & $\varepsilon$ & & & & & .05 & .03 \\
\hline $3 \ldots \ldots \ldots \ldots$ & & .01 & & & & & .05 & \\
\hline $4 \ldots \ldots \ldots \ldots$ & & & & & & & & .03 \\
\hline $5 \ldots \ldots \ldots \ldots$ & 01 & .05 & & & & & & \\
\hline$M d h-\mathrm{B}$ & & & & & & & & \\
\hline $1 \ldots$ & 1 & 1 & 1 & 1 & .3 & 1 & 1 & .92 \\
\hline 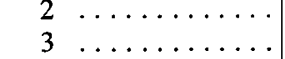 & & & & & .7 & & & .05 \\
\hline $4 \ldots \ldots \ldots \ldots$ & & & & & & & & .03 \\
\hline$M d h-\mathrm{C}$ & & & & & & & & \\
\hline $1 \quad \ldots \ldots \ldots \ldots$ & 1 & 1 & 1 & 1 & 1 & 1 & .90 & \\
\hline $\begin{array}{l}2 \\
2 \\
3\end{array} \ldots \ldots \ldots \ldots$ & & & & & & & & .17 \\
\hline $4 \ldots \ldots \ldots \ldots$ & & & & & & & .10 & \\
\hline$I d h-\mathrm{A}$ & & & & & & & & \\
\hline $1 \ldots \ldots \ldots$ & 1 & .99 & .86 & 1 & 1 & 1 & 1 & 1 \\
\hline $3 \ldots \ldots \ldots \ldots$ & & .01 & .14 & & & & & \\
\hline$P g d-\mathrm{A}$ & & & & & & & & \\
\hline $1 \ldots \ldots \ldots \ldots$ & .67 & .73 & .84 & & & .88 & .90 & 1 \\
\hline $2 \ldots \ldots \ldots \ldots$ & .10 & .07 & & & & 0.06 & .05 & \\
\hline $\begin{array}{l}3 \\
4\end{array} \ldots \ldots \ldots \ldots$ & .19 & .18 & .16 & 1 & 1 & 0.06 & .05 & \\
\hline $5 \quad \ldots \ldots \ldots \ldots$ & .04 & .02 & & & & & & \\
\hline
\end{tabular}




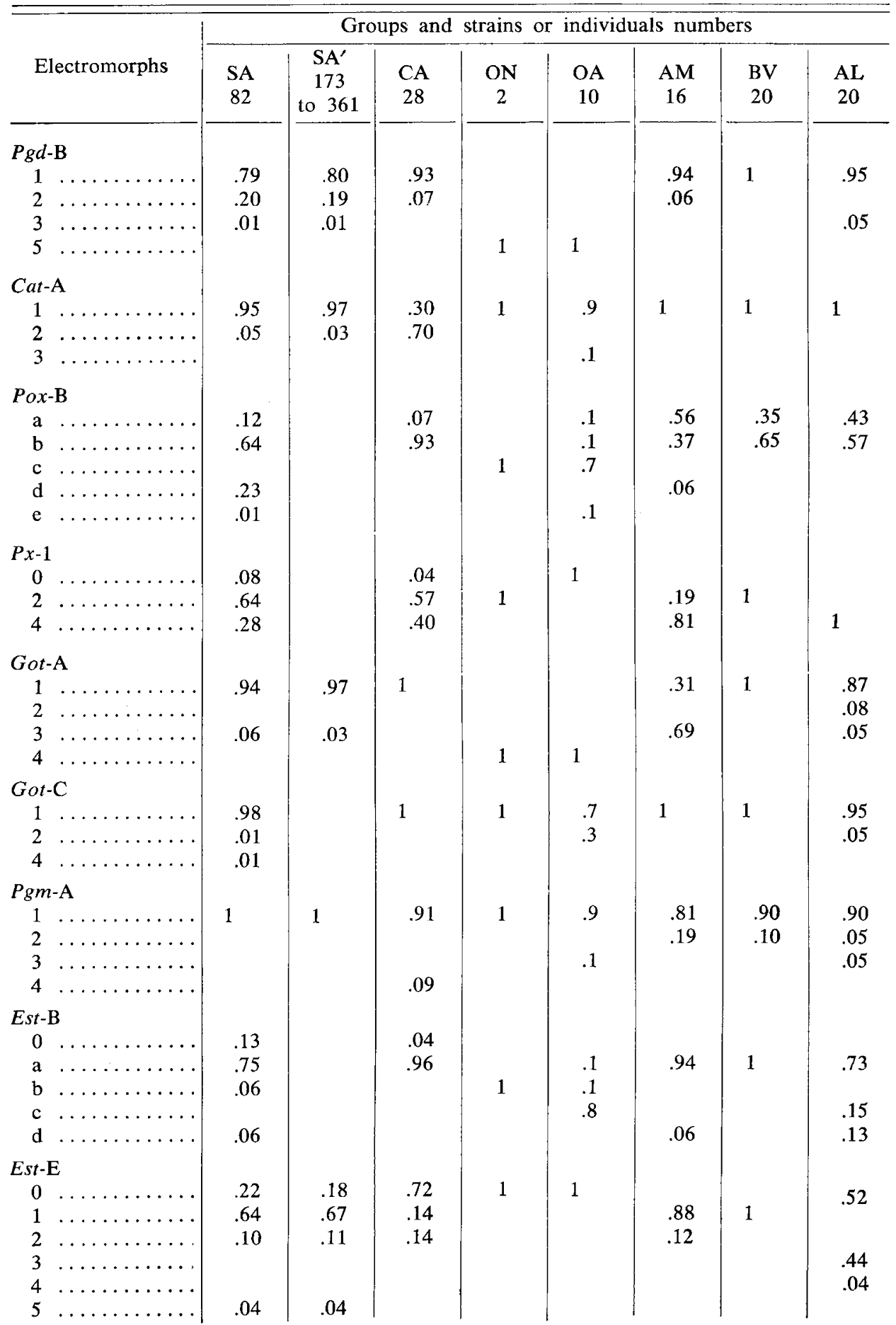




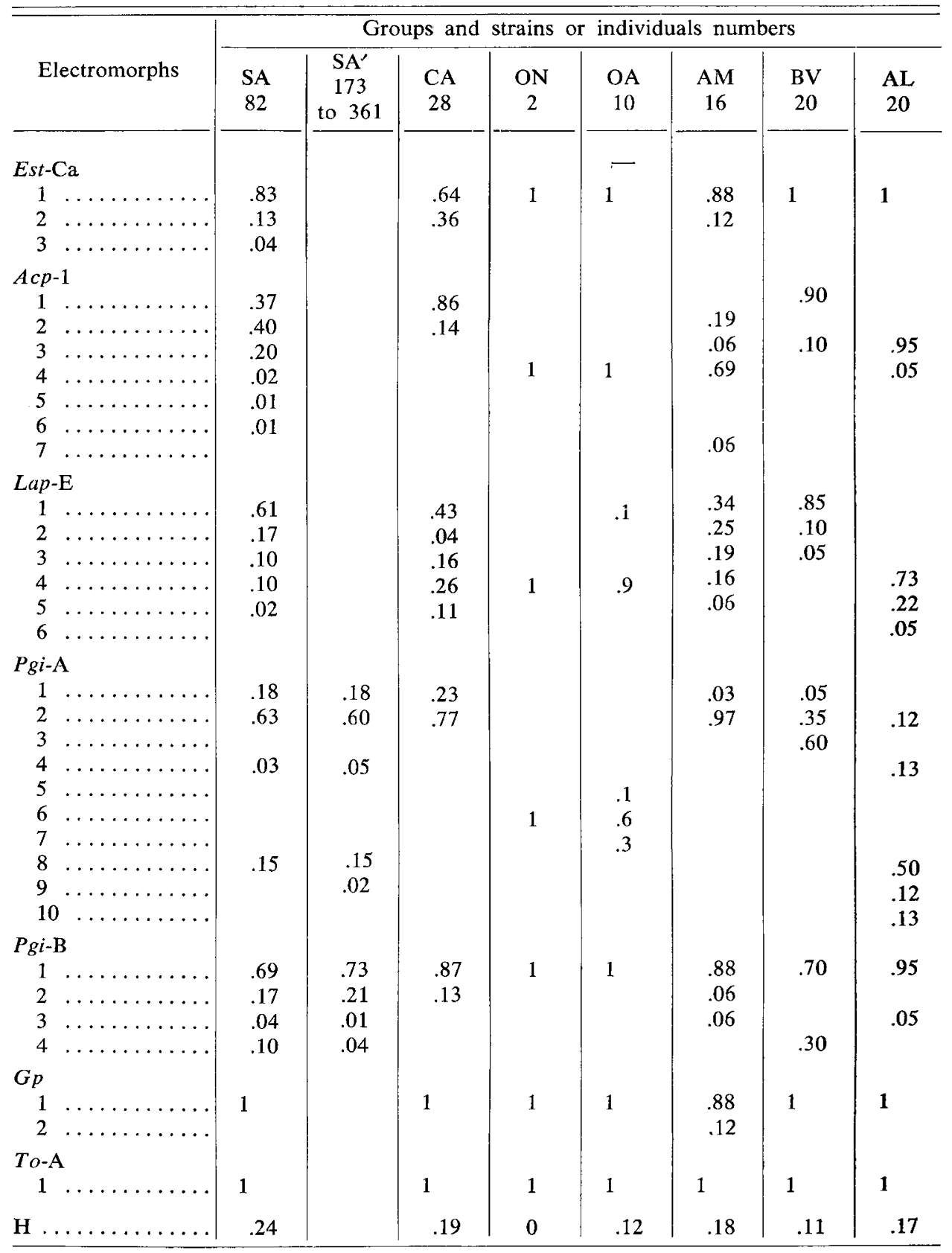

SA : South Asian O. rufipogon (SA' stands for a larger collection); CA : Chinese O. rufipogon ; ON : New Guinean $O$. rufipogon with Australian affinities ; OA : Australian O. rufipogon ; AM : American $O$. rufipogon; $\mathrm{BV}: O$. breviligulata; $\mathrm{AL}: O$. longistaminata; $\mathrm{H}$ is the genic diversity averaged over 24 loci. 


\section{Gene diversity within and between geographic groups or species}

The frequencies of electromorphs at each of the 24 loci are presented in table 2 for the 8 geographical groups, forms or species defined above. When frequencies were averaged between groups of strains, six loci only (25 p. 100) were found to be monomorphic at the 0.95 level. Usually, only one electromorph dominated each group. For the South Asian group, in addition to the above, a number of lines (173 to 361 in total, subgroup $\mathrm{SA}^{\prime}$ ) were studied at 13 loci (tabl. 2); the electromorph frequencies remained fairly similar to those obtained with the 85 strains only.

All electromorphs of the American form are shared with the Asian form with the exception of the rare $G p$-2 electromorph found only in 2 strains that originated in Surinam. However, the electromorph Acp-1.4, that was frequent among American strains was only found in Asia among the strains that originated in Malaysia (see fig. 4). On the contrary, one frequent electromorph Pgi-A3 was peculiar to O. breviligulata.

The electromorph frequencies (for the most polymorphic loci), obtained in different ecogeographical origins of Asian $O$. rufipogon (which is believed to be the direct ancestor of cultivated $O$. sativa) are diagramatically presented in figure 4 along with the basic isozyme patterns of indica and japonica types of cultivated rice. For the South Asian strains, four geographic origins, the life forms and the weedy or non weedy origins were distinguished. Among the Chinese strains, the 3 different geographic origins were distinguished. Geographic clines related to the differentiation in cultivated rice appeared for the electromorph frequencies at a few loci. Cat-A2 was frequent in China only while Est-EO and $A c p-1.1$ were frequent in China and Continental South East Asia only.

The electromorphs of the japonica type were found with a high frequency only in the Chinese strains with the exeption of Est-Ca2. There was more similarities of the indica type with South Asian strains but no particular life form nor geographical origin appeared to be definitively more closely related to it. Electromorphs Pgi-A1 and $P g i-\mathrm{B} 2$ of the indica type were only rarely found anywhere in spontaneous plants.

As a measure of the genetic variability, Nei's gene diversity $\mathrm{H}=1-\Sigma \mathrm{Pi}^{2}$, $\mathrm{Pi}=$ frequency of electromorph $\mathrm{i}$, averaged over the 24 loci was indicated in table 2 . The highest mean gene diversity, $\mathrm{H}=0.25$, was found in South Asian $O$. rufipogon. With $\mathrm{H}=0.19$ and 0.18 , the Chinese and the American $O$. rufipogon also had a relatively large gene diversity. On the other hand, the Australian O. rufipogon and O. breviligulata had a lower value : $H=0.12$ and 0.11 , respectively. With $H=0.17$, the perennial and allogamous $O$. longistaminata had an intermediate value. The 2 «Oceanian » strains from New Guinea were found to have the same isozyme pattern.

The high value of the gene diversity $\mathrm{H}$ for the «South Asian » group did not resulted from its heterogeneity in terms of geographical origins and life forms, since it was also high and varied from 0.14 to 0.25 for single ecogeographic subgroups as indicated in fig. 4. 
Subgroups examined and numbers of strains tested
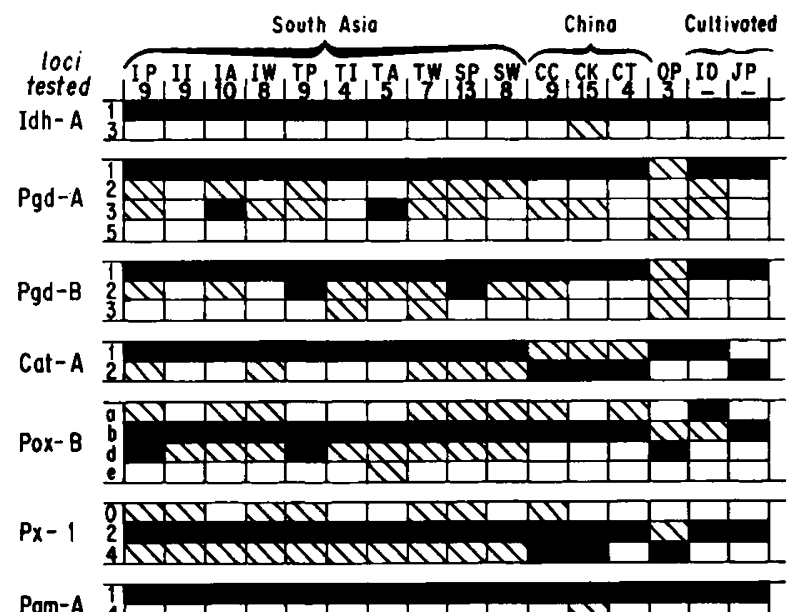

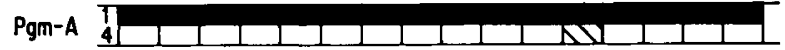

Est- 8
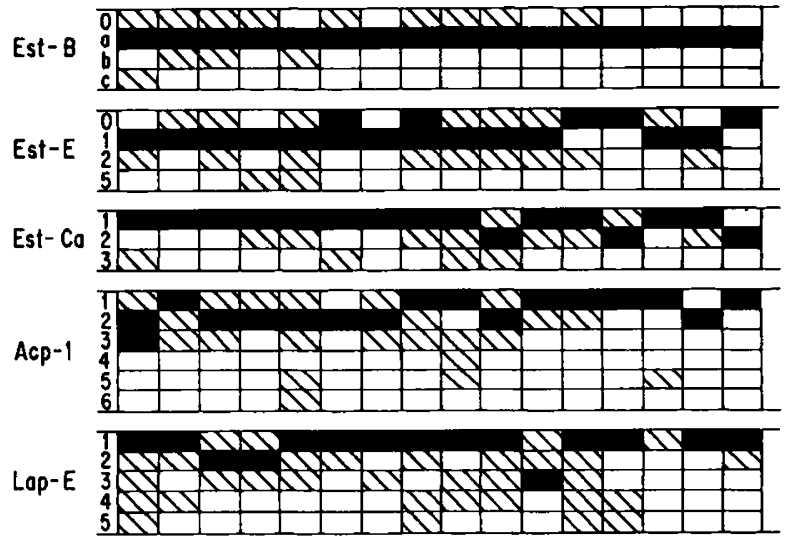

Pgi-A
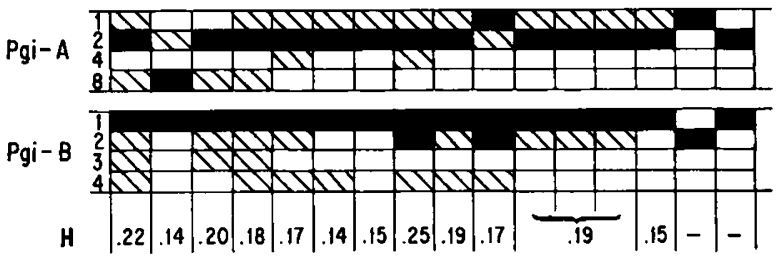

FIG. 4

Diagramatic representation of electromorph frequencies found at the 14 most polymorphic loci in groups of wild or weedy strains of Asian $\mathrm{O}$. rufipogon along the 2 representative isozyme patterns of cultivated O. sativa. For South Asian strains, the 1st letter represents the geographic origins : I for Indian subcontinent, $T$ for continental South-East Asia and $S$ for insular South-East Asia; the 2nd letter stands for Perennial, Intermediate,

Annual or Weedy. For China, CC, CK and CT stand for strains originating in Kwangtung, $K$ wangsi and Taiwan respectively. OP stands for Asian $O$. rufipogon strains from New Guinea, $I D$ and $J P$ for indica and japonica representative patterns of cultivated rice. In each group, the predominant alleles are represented by a black box and rarer alleles (in terms of frequency within each subgroup) are hatched. $H$ is the gene diversity averaged over 24 loci.

Représentation graphique des électromorphes trouvés à 14 locus les plus polymorphes parmi les groupes écogéographiques de la forme asiatique d'O. rufipogon ainsi que dans les 2 formules isozymiques de base des riz cultivés. $H$ : diversité génique de Nei, moyenne sur 24 locus. 


\section{Group analysis of genetic distances between strains}

A rationale for the calculation of genetic distances between individuals (each representing a population) rather than between groups lies in the genetic structure of the species considered. Various reproductive barriers are commonly encountered including autogamy, death or sterility of the F1 plants, ecological segregation and geographical disjunction. In addition, domestication has certainly disturbed the natural genetic structure. Any group constituted is genetically heterogeneous.

Furthermore, the large proportion of loci with no common allele and the largely variable gene diversity in different ecogeographical groups do not allow a reliable comparison in terms of Nei's genetic distances between such groups. In place of that, the table 3 presents various aspects of the genetic divergence among the 8 groups of strains defined in section B :

1) the distribution (median and range of variation) of Nei's genetic distances (D) in strain comparison within and between groups. As the distribution may not be normal, the median value is a better indication than the mean;

2) the number of loci out of 24 with no electromorph in common between groups;

3) the number of loci with no predominant electromorph in common between groups.

In agreement with the multivariate positionning in figure 2 , the highest values of $\mathrm{D}$ were found between the Australian and the non-Oceanian strains, with a median value $(\widehat{D})$ of 0.60 to 0.76 , while $\widehat{\mathrm{D}}$ between $O$. longistaminata and Asian and American strains was 0.45 only. $\widehat{D}$ between the Chinese and South Asian groups is slightly greater than $\widehat{D}$ within these groups $(0.29$ vs 0.25 and 0.20$)$. The interval of variation of D (min-max) was considerable among South Asian strains (0.62), which appeared to be composed of a complex intergrade of genotypes.

More loci share electromorphs between the allopatric $O$. longistaminata and Asian $O$. rufipogon than between the parapatric species $O$. longistaminata and $O$. breviligulata. The distances of Australian O. rufipogon (annual) from O. longistaminata (perennial) and from $O$. breviligulata (annual) were similar. The Australian O. rufipogon exibited however some rare electromorphs typical of Asian O. rufipogon. This explains why it has smaller number of loci with no common electromorph than its New Guinean counterpart which was fixed for a unique electromorph at every locus. All loci shared electromorphs between American and Asian O. rufipogon and O. breviligulata, although predominent electromorphs differed between them.

\section{E. Hidden variability at the two Pgi loci}

Hidden variability was screened by heat treatment at the 2 Pgi loci. The number of strains screened within each geographical group and the «electro-thermomorphs » found are given in table 4 . The data for $O$. breviligulata were taken as recorded by SEcond (1982). Both O. breviligulata and Australian O. rufipogon seemed to have greater hidden variability than other $O$. rufipogon groups. However some perennial strains of $O$. rufipogon could have heterozygous loci, rendering the method less discriminant for them. Within $O$. longistaminata hidden variability seemed also to exist 
TABLE 3

The distribution of genetic distances among individuals within or between groups and the number of loci with no electromorph, or no predominant electromorph in common between the main forms of the Sativa group.

La distribution des distances génétiques entre individus parmi les groupes et le nombre de locus sans allèle (ou sans allèle prédominant) en commun entre les principales formes du groupe Sativa.

\begin{tabular}{|c|c|c|c|c|c|c|c|c|c|c|}
\hline & \multicolumn{10}{|c|}{ Groups and strains or individuals numbers } \\
\hline & $\begin{array}{l}\text { SA } \\
82\end{array}$ & $\begin{array}{l}\text { CA } \\
28\end{array}$ & $\begin{array}{c}\mathrm{ON} \\
2\end{array}$ & $\begin{array}{c}\text { OA } \\
10\end{array}$ & $\begin{array}{c}\mathrm{AM} \\
16\end{array}$ & $\begin{array}{l}\text { BV } \\
20\end{array}$ & $\begin{array}{l}\text { AL } \\
20\end{array}$ & $\begin{array}{c}\text { ID } \\
1\end{array}$ & $\begin{array}{c}\mathrm{JP} \\
1\end{array}$ & $\begin{array}{c}\mathrm{GL} \\
1\end{array}$ \\
\hline $\begin{array}{c}\text { SA } \\
\text { South-Asia }\end{array}$ & $\begin{array}{ll}\min & 0 \\
\operatorname{med} & 0.25 \\
\max & 0.62\end{array}$ & $\begin{array}{l}0.02 \\
0.29 \\
0.62\end{array}$ & $\begin{array}{l}0.34 \\
0.47 \\
0.69\end{array}$ & $\begin{array}{l}0.31 \\
0.61 \\
1.12 \\
\end{array}$ & $\begin{array}{l}0.09 \\
0.30 \\
0.56\end{array}$ & $\begin{array}{l}0.04 \\
0.23 \\
0.61\end{array}$ & $\begin{array}{l}0.18 \\
0.45 \\
0.81\end{array}$ & $\begin{array}{l}0.06 \\
0.23 \\
0.44\end{array}$ & $\begin{array}{l}0.09 \\
0.28 \\
0.48\end{array}$ & $\begin{array}{l}0.04 \\
0.22 \\
0.47\end{array}$ \\
\hline $\begin{array}{c}\text { CA } \\
\text { China }\end{array}$ & $\begin{array}{lc}\text { (a) } & 0 \\
\text { (b) } & (3)\end{array}$ & $\begin{array}{l}0 \\
0.20 \\
0.56\end{array}$ & $\begin{array}{l}0.36 \\
0.49 \\
0.69\end{array}$ & $\begin{array}{l}0.30 \\
0.64 \\
0.98\end{array}$ & $\begin{array}{l}0.12 \\
0.34 \\
0.64\end{array}$ & $\begin{array}{l}0.06 \\
0.25 \\
0.54\end{array}$ & $\begin{array}{l}0.24 \\
0.46 \\
0.94\end{array}$ & $\begin{array}{l}0.09 \\
0.31 \\
0.48\end{array}$ & $\begin{array}{l}0 \\
0.14 \\
0.37\end{array}$ & $\begin{array}{l}0.07 \\
0.23 \\
0.42\end{array}$ \\
\hline $\begin{array}{c}\text { ON } \\
\text { New-Guinea }\end{array}$ & $\begin{array}{c}5 \\
(9)\end{array}$ & $\begin{array}{c}7 \\
(9)\end{array}$ & $\overrightarrow{0}$ & $\begin{array}{l}0.09 \\
0.16 \\
0.40\end{array}$ & $\begin{array}{l}0.40 \\
0.53 \\
0.61\end{array}$ & $\begin{array}{l}0.47 \\
0.47 \\
0.69\end{array}$ & $\begin{array}{l}0.51 \\
0.60 \\
0.81\end{array}$ & $\frac{0.52}{0.52}$ & $\begin{array}{l}0.53 \\
0.53\end{array}$ & $\frac{0.47}{-}$ \\
\hline $\begin{array}{c}\text { OA } \\
\text { Australia }\end{array}$ & $\begin{array}{c}4 \\
(11)\end{array}$ & $\begin{array}{c}5 \\
(11)\end{array}$ & $\begin{array}{c}2 \\
(4)\end{array}$ & $\begin{array}{l}0 \\
0.09 \\
0.34\end{array}$ & $\begin{array}{l}0.40 \\
0.60 \\
1.10\end{array}$ & $\begin{array}{l}0.40 \\
0.61 \\
1.10\end{array}$ & $\begin{array}{l}0.47 \\
0.76 \\
1.26\end{array}$ & $\begin{array}{l}0.55 \\
0.68 \\
0.98\end{array}$ & $\begin{array}{l}0.53 \\
0.68 \\
0.86\end{array}$ & $\begin{array}{l}0.47 \\
0.61 \\
1.10\end{array}$ \\
\hline $\begin{array}{c}\text { AM } \\
\text { America }\end{array}$ & $\begin{array}{c}0 \\
(3)\end{array}$ & $\begin{array}{c}0 \\
(5)\end{array}$ & $\begin{array}{c}7 \\
(9)\end{array}$ & $\begin{array}{c}6 \\
(10)\end{array}$ & $\begin{array}{l}0 \\
0.16 \\
0.56\end{array}$ & $\begin{array}{l}0.13 \\
0.29 \\
0.60\end{array}$ & $\begin{array}{l}0.24 \\
0.44 \\
0.76\end{array}$ & $\begin{array}{l}0.15 \\
0.32 \\
0.41\end{array}$ & $\begin{array}{l}0.21 \\
0.38 \\
0.50\end{array}$ & $\begin{array}{l}0.14 \\
0.30 \\
0.45\end{array}$ \\
\hline $\begin{array}{c}\text { BV } \\
\text { O. } \\
\text { breviligulata }\end{array}$ & $\begin{array}{c}0 \\
(2)\end{array}$ & $\begin{array}{c}0 \\
(3)\end{array}$ & $\begin{array}{c}8 \\
(9)\end{array}$ & $\begin{array}{c}7 \\
(11)\end{array}$ & $\begin{array}{c}0 \\
(4)\end{array}$ & $\begin{array}{l}0 \\
0.09 \\
0.29\end{array}$ & $\begin{array}{l}0.30 \\
0.45 \\
0.80\end{array}$ & $\begin{array}{l}0.16 \\
0.18 \\
0.28\end{array}$ & $\begin{array}{l}0.14 \\
0.24 \\
0.35\end{array}$ & $\begin{array}{l}0 \\
0.09 \\
0.23\end{array}$ \\
\hline $\begin{array}{l}\mathrm{AL} \\
\text { O. longista- } \\
\text { minata }\end{array}$ & $\begin{array}{c}1 \\
(6)\end{array}$ & $\begin{array}{c}2 \\
(7)\end{array}$ & $\begin{array}{c}9 \\
(10)\end{array}$ & $\begin{array}{c}9 \\
(11)\end{array}$ & $\begin{array}{c}2 \\
(6)\end{array}$ & $\begin{array}{c}4 \\
(6)\end{array}$ & $\begin{array}{l}0.03 \\
0.19 \\
0.39\end{array}$ & $\begin{array}{l}0.42 \\
0.50 \\
0.63\end{array}$ & $\begin{array}{l}0.42 \\
0.52 \\
0.73\end{array}$ & $\begin{array}{l}0.30 \\
0.45 \\
0.60 \\
\end{array}$ \\
\hline $\begin{array}{l}\text { ID } \\
\text { indica }\end{array}$ & $\begin{array}{c}0 \\
(3)\end{array}$ & $\begin{array}{c}0 \\
(6)\end{array}$ & $\begin{array}{c}9 \\
(10)\end{array}$ & $\begin{array}{c}7 \\
(12)\end{array}$ & $\begin{array}{c}0 \\
(4)\end{array}$ & $\begin{array}{l}2 \\
(4)\end{array}$ & $\begin{array}{c}6 \\
(8)\end{array}$ & - & $\begin{array}{l}-30 \\
-\end{array}$ & $\overline{0.22 *}$ \\
\hline $\begin{array}{c}\text { IP } \\
\text { japonica }\end{array}$ & $\begin{array}{c}0 \\
(4)\end{array}$ & $\begin{array}{c}0 \\
(1)\end{array}$ & $\begin{array}{c}9 \\
(10)\end{array}$ & $\begin{array}{c}7 \\
(11)\end{array}$ & $\begin{array}{c}3 \\
(6)\end{array}$ & $\begin{array}{c}2 \\
(4)\end{array}$ & $\begin{array}{c}4 \\
(8)\end{array}$ & $\begin{array}{c}5 \\
(7)\end{array}$ & - & $\begin{array}{l}\overrightarrow{0.20} \\
-\end{array}$ \\
\hline$\underset{\mathrm{GL}}{\text { Olaberrima }}$ & $\begin{array}{c}0 \\
(2)\end{array}$ & $\begin{array}{c}0 \\
(3)\end{array}$ & $\begin{array}{c}8 \\
(9)\end{array}$ & $\begin{array}{c}6 \\
(11)\end{array}$ & $\begin{array}{c}1 \\
(4)\end{array}$ & $\begin{array}{c}0 \\
(0)\end{array}$ & $\begin{array}{c}4 \\
(6)\end{array}$ & $\begin{array}{c}3 \\
(4)\end{array}$ & $\begin{array}{c}3 \\
(4)\end{array}$ & - \\
\hline
\end{tabular}

* These value were $0.51,0.35$ and 0.34 when computed from 40 loci (SECOND, 1982).

SA : South Asian $O$. rufipogon; CA : Chinese $O$. rufipogon; ON : New Guinean $O$. rufipogon with Australian affinities; OA : Australian O. rufipogon; AM : American O. rufipogon; BV : $O$. breviligulata ; AL : O. longistaminata ; ID, JP, GL : the indica, japonica, glaberrima types of cultivated rice presented by their basic isozyme patterns respectively.

Above and on the diagonal : the minimum, median and maximum values of Nei's genetic distances calculated on 24 loci in all combinations of pairs of strains. Below the diagonal a) the number of loci with no electromorph in common b) in parentheses, the number of loci differing in predominent allele. 
G. SECOND

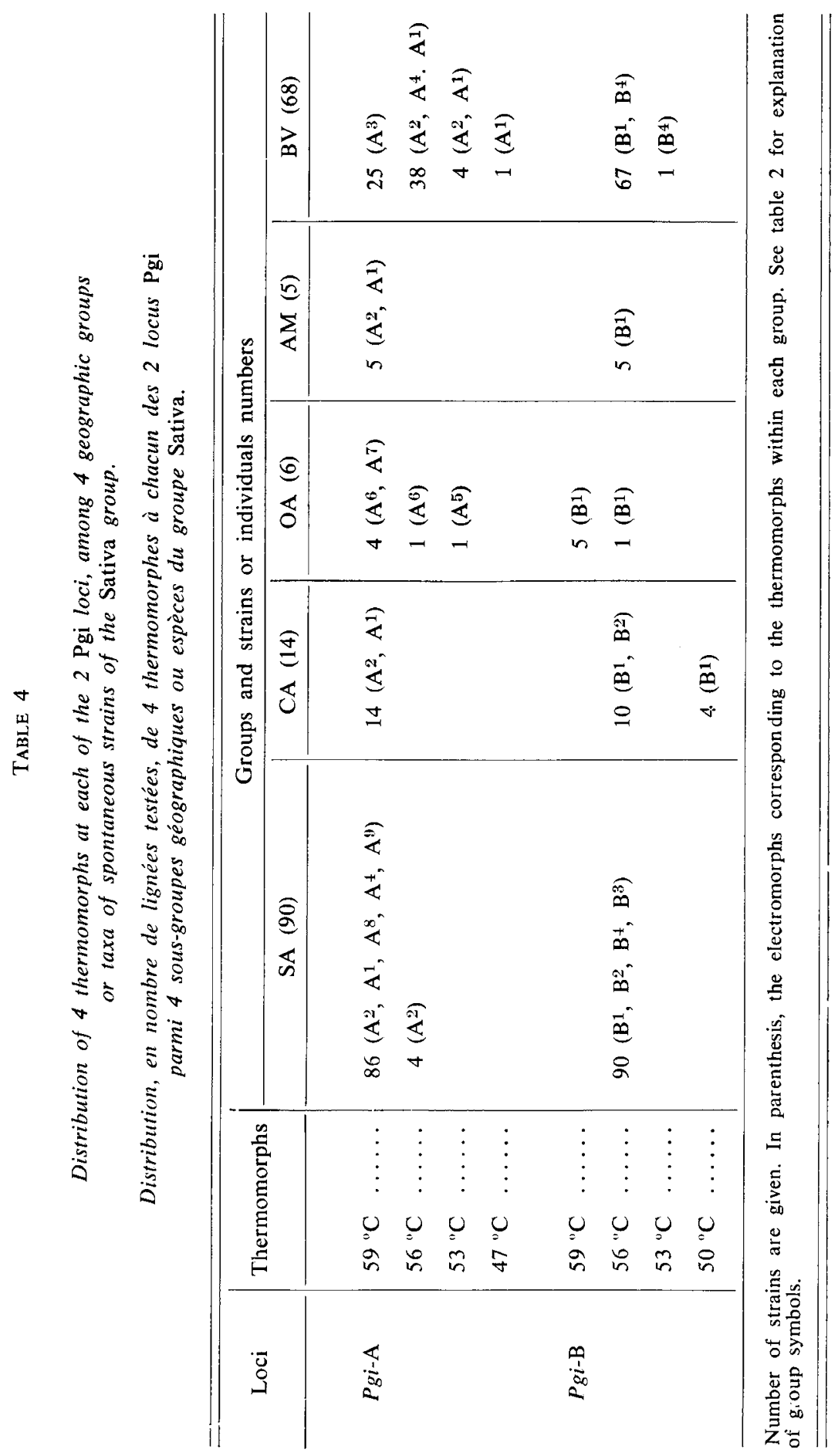


for the same loci. Frequencies of thermomorphs were not determined in this species because of the high heterozygosity expected among its strains. Only a few electromorphs were common between $O$. breviligulata and other groups at the Pgi-A locus and between Australian $O$. rufipogon and other groups at the Pgi-B locus. Thus, the hidden variability study only reinforced the trend of variation found in simple electrophoretic survey. In particular, it reinforced the differentiation of $O$. breviligulata and the Oceanian form of $O$. rufipogon on the one hand but the lack of differentiation of the American form of $O$. rufipogon on the other hand.

\section{Discussion}

A high degree of isozyme polymorphism was revealed within the $O$. sativa species group. We may discuss successively the parental relationships between its various forms or species and how such differentiation has arisen.

\section{A. The pattern of interrelationships among the Sativa group}

The Sativa group was defined on the basis of meiotic chromosome pairing (MoRINAGA, 1964) as well as by statistical taxonomical methods based on morphological and physiological characters (MORISHIMA \& OKA, 1960). In the subsequent work of the 2 last authors, the Sativa group was considered as composed of 2 species on the basis of the length of the ligule only : $O$. breviligulata and $O$. perennis.

Morishima (1969) studied the phenetic similarities among strains of O. perennis on the basis of morphological and F1 sterility relationships. No reliable sample originating in China was however available at that time. Based on morphological characters only, the overall greatest dissimilarities were found between the annual and perennial life forms, irrespective of their geographic origins. Next, strains from each continent, Asia, Africa and America, tended to form a different cluster. The pattern of F1 sterility relationships coincided largely with the geographical groups but not with the classification in life forms. Even within the Asian group, a very wide range of F1 pollen sterility relationships was found within and between the annual, intermediate and perennial life forms. In New Guinea, strains related to both the Oceanian and the Asian groups, were found.

It appears that the pattern of interrelationships in the present study is in global disagreement with the morphological similarities. On the other hand, it is largely in agreement with the $\mathrm{F} 1$ pollen relationships :

- The Oceanian form is the most distantly related to others.

- The range of $F 1$ pollen fertilities between the American and the Asian forms fall into the range found within the Asian form itself.

- The pattern of F1 pollen relationships within the Asian form is not directely related with its subdivision into life forms.

Our work included the whole Sativa group. We were led to distinguish 7 groups of wild strains. In addition to the 4 geographical groups of $O$. perennis defined by Morishima (1969), they corresponded (1) to O. breviligulata (whose distinction as a 
parallel evolutive series to $O$. perennis (ОКА, 1974) appears to be meaningless and based on the length of the ligule only) (2) a Chinese form and (3) a New Guinean form of $O$. rufipogon. The proposed classification of the Sativa group is given in table 5 in comparison with the nomenclature used in the papers by MORISHIMA \& Ока cited above.

\section{TABLE 5}

Subdivision of the Sativa group.

Classification du groupe Sativa.

\begin{tabular}{l|l}
\hline $\begin{array}{c}\text { As per Morishima \& OKa (1960) } \\
\text { and Morishima (1969) }\end{array}$ & \multicolumn{1}{c}{ Present paper } \\
\cline { 1 - 2 } $\begin{array}{l}\text { O. perennis Moench. Asian form } \\
\text { O. perennis, Oceanian form }\end{array}$ & $\begin{array}{l}\text { O. rufipogon Griff., South Asian form } \\
\text { O. rufipogon, Chinese form } \\
\text { O. rufipogon, Australian form } \\
\text { O. rufipogon, Oceanian - New Guinean form }\end{array}$ \\
O. perennis, African form & $\begin{array}{l}\text { O. rufipogon, American form } \\
\text { O. longistaminata, A. Chev. \& Roehr. }\end{array}$ \\
\hline \hline
\end{tabular}

The Australian form of $O$. rufipogon was recently named $O$. meridionalis (NG et al., 1981). We can only agree with the recognition of an Australian form distinct form the others. However, as in the case of $O$. longistaminata, no simple key of determination is available besides biochemical markers. Still $O$. longistaminata is isolated from its relatives by reproductive barriers particularly developped (CHU et al., 1969) while introgression of genes between Asian and Oceanian O. rufipogon seems to be easier and to have had a large impact on the variability of Oceanian $O$. rufipogon as is discussed in the following section. Furthermore, Oceanian O. rufipogon appears to be composed of 2 distinct forms at least (Australian and New Guinean). That is why we retained them as part of $O$. rufipogon but recognise $O$. longistaminata as a distinct species.

$O$. breviligulata and $O$. longistaminata are 2 species endemic to Africa. On the contrary, $O$. rufipogon is a complex species. While the divergence of an Oceanian form, first suggested by Morishima (1969), was fully corroborated here, it came as a surprise that the American form was very closely related to the Asian form. All frequent electromorphs in the American form were found in Asia, particularly in some strains from Indonesia, that were unfortunately poorly represented in our collection.

Also remarkable was the distinction of some Chinese strains related to the japonica type of cultivars. In China, wild rice is distributed not only in Southern Pro- 
vinces but also in Kiangsi and Hunan Provinces up to $28^{\circ} \mathrm{N}$, that is in the Yangtse river basin, in habitats isolated from rice fields (published in Renmin Erbao, Aug. 6, 1983, Pr WANG XIANG Ming, personnal communication). Only indica type cultivars ( « Hsien ») are cultivated in lowlands in these areas. It appeared from various informations and observations that the collection studied from Kwangsi Province is very likely to be representative of the wild rice found in isolated areas in South-China. In contrast, the collection from Kwangtung Province had been harvested and multiplied in contact with the local cultivars (hence probably indica type). This is in accordance with the morphological appearance and the observed heterozygosity in the 2 collections : from Kwangsi, most strains looked typically wild and had a low electromorph heterozygosity. From Kwangtung, all strains looked like morphological hybrids with cultivars and displayed a high electromorph heterozygosity : they may contain genes from indica type cultivars.

As to the collection that originated in Taiwan, it could have introgressed genes from japonica varieties introduced in the lowlands of Taiwan at the time of their collection (see OKA \& ChANG, 1961 ; KiANG et al., 1979). However, the present data suggest that it could also be of an original constitution close to the collection studied from Kwangsi Province.

The description of a Chinese form of $O$. rufipogon seems appropriate, in spite of the relatively limited and poorly documented collection that was studied, because it showed original features compared to the South and South-East Asian forms well represented in our collection.

All 3 geographic forms of O. rufipogon which are most closely related to the cultivated rice (South Asian, Chinese and American forms) were the most polymorphic of the whole Sativa group.

\section{B. An evolutionary interpretation}

Now the question is how such differentiation arose. It seems reasonable to assume that divergence in isozymes is correlated with time of separation among isolated populations. The validity of using the molecular clock (« electrophoretic clock » in our case) in the study of evolution of Oryza was discussed earlier (SECOND, 1984 c, $1984 \mathrm{~d}$ ). Reasonable estimate of dates (of divergence) which are consistant with paleogeography are obtained for both the Sativa and the Latifolia group of species.

As pointed out by SARICH (1977), attempts to use electrophoretic data as a clock should take into consideration that the rate of fixation of mutations varies greatly among loci. Accordingly, the accumulation of electrophoretic distance is not a linear function of time. In the present case, the loci Pox-B,Est-B and E, Acp-1, Lap-E and $P g i$-A and B may be considered as rapidly evolving loci in view of their great polymorphism among various representatives of the genus Oryza (unpublished data). Other loci would be more slowly evolving ones although no clear limit can be fixed between the two classes. Accordingly, the medium curve of SARICH (1977, fig. 2) was tentatively used as a calibration of the clock. It gives a time around 15 millions years for the divergence of the Australian form of $O$. rufipogon and non Oceanian forms. This dating corresponds to the Miocene collision of Laurasia with the Australia/New Guinea shard of Gondwanaland (see Whitmore, 1981), an event which is 
believed to have created Malesia and allowed considerable land migration from Asia to Australasia (see Keast, 1971; Whitmore, 1981). It is thus very much plausible.

Assuming the reasonableness of the above calibration of the electrophoretic clock, we obtained the following estimated dates based on the median values of strain to strain distances between groups (tabl. 3) :

- 7 m.y. for the divergence between $O$. longistaminata and both $O$. breviligulata and Asian O. rufipogon;

- 2 or 3 m.y. years for the divergence between the ancestors of indica, japonica and glaberrima type of cultivated rice.

These estimates are fully compatible with what is known about the paleoenvironment, information about which was used previously to develop an evolutionary scenario for the genus Oryza (SECOND, 1983, 1984 a, 1984 b). Only arguments but no proof can be put forward, so it is tentative only. It may be summarized as follows.

The above times of divergence indicate the existence of the Sativa group during the Miocene epoch, that is at a time when tropical and sub-tropical climates were distributed further away from the Equator than at present. This is consistent with the observation made in the introduction of a primitiveness of the tribe Oryzeae and with the adaptation to humid areas of the tropics of genus Oryza.

Because Oryza species adapted to forest environments are primarily found in Asia, or seem to have migrated very recently from there, an Eurasiatic distribution of the genus during the Tertiary period was assumed. The genus was introduced to Australasia as stated above but remained isolated from Asia according to the socalled "Wallace line». Its introduction into Africa seems to have occurred through a relatively arid environment. Either a few founders migrated across an inhospitable environment or a continuous distribution from Asia to Africa was interrupted due to cooling of the climate and/or increasing aridity. In accordance with their ecological requirements, the possibilities of migration were interrupted earlier $(7 \mathrm{~m} . \mathrm{y}$.$) for$ the perennial $O$. longistaminata than for the annual $O$. breviligulata $(2-3 \mathrm{~m} . \mathrm{y}$.). The particularly strong reproductive barrier found between the 2 African species could be due to its reinforcement after their distributions overlapped.

Migration of Hipparian fauna was possible across the Himalayan range until 2 or 3 millions years ago. Wild rice, at least annual forms, migrated along with the fauna. The climate was suitable for rice at that time in Central Asia. Wild rice probably existed in North China and certainly in Central China until historical time.

Migration of rice would have been possible between South Asia and the SouthEast Asian archipelago at the time of glaciations as the sea level was lowered (see fig. 1). However, a strong geographic barrier due to thickly forested mountains remained between South Asia and China until historical time.

The naturally big and abundant seeds of rice may have evolved as an adaptation to the habitat disturbance by the feet of large animals. The seeds buried deep in a muddy substratum which later dries up are protected from predators and parasites but need more energy to germinate. Man was attracted by the seeds and domesticated rice in Neolithic times. Domestication proceeded probably independently in 
China, South Asia and Africa, as suggested earlier (SEcond, 1982) and by the present finding of a trend of differentiation, related to japonica type cultivars, of $O$. rufipogon in China. However, Man still harvests wild rice at present in Africa and in India. He also uses wild rice as fodder for animals and as a medicine.

The introduction of wild rice into America is certainly recent as judged from the similarities in isozyme patterns with their Asian relatives, particularly those of South East Asia. As wild rice seems to have been present in South America at the end of the $18^{\text {th }}$ century (Gumilla, 1791) it may have been introduced by the Spaniards during their journeys from South East Asia to South America. This is in contradiction with the conclusion of Morishima (1969) who assumed inedependent evolution of the 4 geographic forms of the Sativa group isolated by Oceans. However, isozymes may be taken as better markers of phylogenetic relationships than morphological similarities. Study of the distribution of grass genera throughout the world has led to the conclusion that «trans-oceanic dispersal may occur over moderate distances, but that it does not provide a satisfactory general explanation for global distributions» (CLAYTON, 1975). This postulate leaves only 2 alternatives for the existence of wild rice in America : many millions of years of independent evolution or an introduction by Man a few hundred years ago. Clearly, our results support the second alternative. Hence, evolution of wild rice in America is a case of rapid morphological and ecological adaptation.

Extensive migration through the activity of Man is likely to have occurred both for wild and cultivated species within the Old World as well. An example of new forms arising from introgressions between 2 geographical groups may be in the New Guinean strains with overall affinity with Australian $O$. rufipogon, but also with electromorphs typical of Asian $O$. rufipogon. The figure 5 summarizes the proposed phylogenetic relationships for the Sativa group, based on the estimated divergence time and the recent interchanges between geographical isolates.

Asia appears to be a central area for the evolution of the Sativa group. It is 1) the relict area of a probably much more wide-spread distribution in Eurasia before climatic cooling; 2) the area where domestication was most active and successful ; 3) the area where the disturbance of primitive habitats and primitive genetic and geographic structure due to the activity of Man has been most pronounced. The cumulative effects of these factors explain the complex intergrade of various genotypes found within Asian O. rufipogon.

Several authors have proposed that, in the past, distinction of an annual and a perennial life form in Asian $O$. rufipogon was more pronounced that at present. If such was the case, a recent break down of reproductive barriers or isolation due to transportation of seeds by Man, concomitant with the opening up of new ecological niches would explain the complex intergrade of genotypes found at present in Asian $O$. rufipogon. There is also a greater diversity within the Asian $O$. rufipogon than in the cultivated types, including indica, japonica and glaberrima. This can be explained if we assume that cultivation of rice started with the annual life form which, as discussed above may have been much more distinct than at present and may have migrated between Africa, South Asia and China long after the migration of the perennial form was interrupted. In other words, the cultivated forms may represent a relatively narrow genetic base, established early in the history of domestication of rice and maintained because of selfing and selection. 


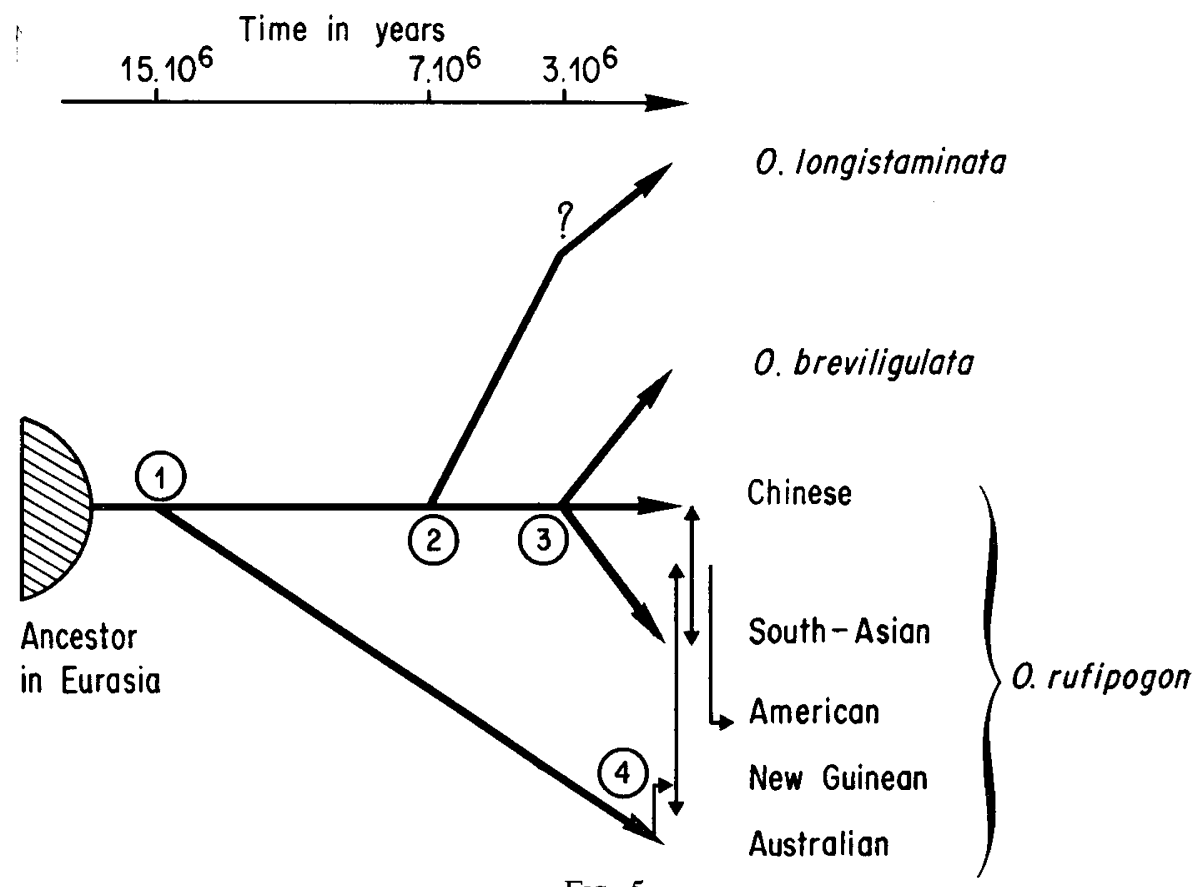

FIG. 5

Phylogenetic tree of the main geographic forms or species of the Sativa group as deduced from its genetic structure at 24 isozyme loci. The absolute time scale represents provisional estimates based on the electrophoretic clock. The main branching points correspond to : 1, migration to Australasia; 2, migration to Africa of a perennial form

(the questionned deviation stands for possible introgression in the past between the 2 endemic African species); 3, migration to Africa of an annual form and emergence of the Himalaya as a geographic barrier to the migration of rice; 4 , introgression of genes of the Asian form by the Oceanian form of $\mathrm{O}$. rufipogon. Vertical arrows account for the main genetic interchanges due to the cultural activity of man.

Arbre phylogénétique résumant les relations évolutives entre formes géographiques ou espèces du groupe Sativa.

The wild rice studied from South Asia had been mostly collected along the main roads or in cultivated areas, that is in newly established ecological niches. To look more closely into the pattern of interrelationships within Asian O. rufipogon in relation with its domestication, and to store its diversity, it would be necessary to start with building an extensive collection of what remains of wild rices in remote areas of Asia. The present report was aimed to suggest the opportunity for a more global study of molecular markers in a better assembled and structured collection. The conclusions would be more strongly established and refined. However the author is confident that the global biogeographic structure described here is essentially correct. 


\section{Acknowledgements}

The electrophoresis work was done during my stay in National Institute of Genetics, Japan, financially supported by O.R.S.T.O.M. and N.I.G. It could not have been achieved without the warm cooperation of Drs T. Endo, S. IYAma, H.I. OKA, H. Morishima and Y. Sano. I thank Drs. J. DeJardin and L. Marchais for their help and advices in the statistical analyses. I appreciate greatly the critical reading of the manuscript by Drs. J. Antonovics, J. David, H.I. Oka, G. Valdeyron and one anonynous referee.

\section{References}

ChU Y.E., OKA H.I., 1970. Introgression across isolating barriers in wild and cultivated Oryza species. Evolution, 24, 344-355.

Chu Y.E., Morishima H., OKa H.I., 1969. Reproductive barriers distributed in cultivated rice species and their wild relatives. Jpn. J. Genet., 44, 207-233.

Clayton W.D., 1975. Chorology of the genera of Gramineae. Kew Bulletin, 30, 111-132.

Endo T., Morishima H., 1983. Current status of isozyme research in individual plant species. 6. - Rice. In : TANKSLEY S.D., ORTON J.J. (ed.), Isozymes in Plant Genetics and breeding, 318 pp., Elsevier Isozyme Monograph, Amsterdam.

Gumilla J., 1791. Historia natural, civil y geographica de las naciones situadas en las rivieras del Rio Orinoco. 2 vol., Barcelona (citations in 38th Annual Report of Smithsonian Institution, Bureau of American Ethnology, 1916-1917, p. 219).

KEAST A. (ed), 1981. Ecological biogeography of Australia. 2 vol., W. Junk bv publishers, The hague.

Kiang Y.T., Antonovics J., Wu L., 1979. The extinction of wild rice (Oryza perennis formosana) in Taiwan. J. Asian Ecology, 1, 1-9.

Kung S., 1976. Tabacco fraction 1 protein : a unique genetic marker. Science, 191, 429-434.

Morinaga T., 1964. Cytogenetical investigations on Oryza species. Symposium sponsored by the International Rice Research Institute, Los Banos, Philippines, February 4-8, 1963. Rice genetics and cytogenetics, 91-103, Elsevier, Amsterdam.

Morishima H., 1969. Phenetic similarity and phylogenetic relationships among strains of Oryza perennis, estimated by methods of numerical taxonomy. Evolution, 23, 429-443.

Morishima H., OKa H.I., 1960. The pattern of interspecific variation in the genus Oryza: its quantitative representation by statistical methods. Evolution, 14, 153-165.

Morishima H., Oka H.I., Chang W.T., 1961. Directions of differentiation in populations of wild rice, Oryza perennis and O. sativa f. spontanea. Evolution, 15, 326-339.

NaYar N.M., 1973. Origin and Cytogenetics of rice. Adv. Genet., 17, 153-292.

NeI M., 1975. Molecular population genetics and evolution, 278 pp., North Holland, Amsterdam.

Ng N.Q., Chang T.T., Williams J.T., Hawkes J.G., 1981. Morphological studies of Asian rice and its related wild species and the recognition of a new Australian taxon. Biol. J. Linn. Soc., 16, 303-313.

OKA H.I., 1958. Intervarietal variation and classification of cultivated rice. Ind. J. Genet. Pl. Breed., 18, 79-89.

OKA H.I., 1974. Experimental studies on the origin of cultivated rice. Genetics, 78, 475-486.

OKa H.I., Chang W.T., 1961. Hybrid swarms between wild and cultivated species, Oryza perennis and $O$. sativa. Evolution, 15, 418-430.

Pai C., Endo T., OKa H.I., 1973. Genic analysis for peroxydase isozymes and their organ specificity in Oryza perennis and O. sativa. Can. J. Genet. Cytol., 15, 845-853. 
PaI C., Endo T., OKa H.I., 1975. Genic analysis for acid phosphatase isozymes in Oryza perennis and O. sativa. Can. J. Genet. Cytol., 14, 637-650.

Pielou E.C., 1969. An introduction to mathematical ecology. Wiley, Interscience, New York.

SARICH V.M., 1977. Rates, sample sizes, and the neutrality hypothesis for electrophoresis in evolutionary studies. Nature, 265, 24-28.

SECOND G., 1982. Origin of the genic diversity of cultivated rice (Oryza spp.) : study of the polymorphism scored at 40 isozyme loci. Jpn. J. Genet., 57, 25-57.

Second G., 1983. The study of isozymes in relation to the distribution of the genus Oryza in the Palaeoenvironment and the subsequent origin of cultivated rice. Conference on the Palaeoenvironment of East Asia from the Mid-Tertiary. Hong-Kong, January 7-12, 1983. Evolution of East Asia Environment, vol. II, 664-682, Centre of Asian studies, Hong-Kong.

SECOND G., 1984 a. A new insight into the genome differentiation in Oryza L. through isozymic studies. In : Sharma A.K.. Sharma Archana (ed.), Advances in Chromosomes and Cell Genetics, New Delhi Oxford and IBH (in press).

SECOND G., 1984 b. A different rates of genome divergence presumed between two species groups in the genus Oryza L. The Nucleus, 27, 44-48.

SECOND G., 1984 c. Geographical origins, genetic diversity and the molecular clock hypothesis in the Oryzeae. In : JACQUARD P., Heim G., Antonovics J. (eds), Genetic differentiation and dispersal in plants, NATO Workshop Proceedings series, Springer Verlag (in Press).

SECoND G., 1984 d. Relations évolutives chez le genre Oryza et processus de domestication des riz. 171 pp., Thèse Doctorat d'Etat. Université Paris-Sud, Orsay.

SECOND G., MoRISHIma H., 1981. Mendelian segregation analysis at 3 isozyme loci in rice cultivars. Natl. Inst. Genet. Mishima., 1980, Annual report, p. 118.

Second G., Trouslot P., 1980. Electrophorèse d'enzymes de riz (Oryza L.). Travaux et Documents, 120, O.R.S.T.O.M., Paris.

Stebbins G.L., Jr., 1956. Cytogenetics and evolution of the grass family. Am. Bot., 43, 890-905.

TAteoka T., 1957. Miscellaneous papers on the phylogeny of Poaceae (10). Proposition of a new phylogenetic system of Poaceae. J. Jpn. Bot., 32, 275-287.

Withmore T.C. (ed.), 1981. Wallace's line and plate tectonics, 90 pp., Clarendon Press, Oxford. 